3 Cotter PD, Baumann M, Bishop DF. Enzymatic defect in $\mathrm{X}$-linked sideroblastic anaemia: molecular evidence for erythroid delta-aminolevulinate synthase deficiency. Proc Natl Acad Sci USA 1992; 89: 4028-36.

4 Bootsma D, Hoeijmakers JHJ. Engagement with transcription. Nature 1993; 363: 114-5.

5 Stefanini M, Vermeulen W, Weeda G, et al. A new nucleotide-excision-repair gene associated with the disorder trichothiodystrophy. Am $\mathcal{F}$ Hum Genet 1993; 53: 817-21. 6 Gibbons RJ, Suthers GK, Wilkie AOM, et al. X-linked $\alpha$-thalassemia/mental retardation (ATR-X) syndrome: localisation to $\mathrm{Xq} 12-\mathrm{q} 21.31$ by $\mathrm{X}$ inactivation and linkage analysis. Am f Hum Genet 1992; 51: 1136-49.

7 Hordinsky MK, Briden B, Berry SA. Friable hair, urea cycle dysfunction and trichothiodystrophy. Curr Probl Dermatol 1987; 17: 52-60.

\title{
Growth hormone deficiency and empty sella in DIDMOAD syndrome: an endocrine study
}

\author{
Ashraf T Soliman, Bhasker Bappal, Assim Darwish, Anna Rajab, Maurice Asfour
}

\begin{abstract}
Two girls with DIDMOAD syndrome are presented. One also had severe megaloblastic-sideroblastic anaemia and the other several neurological manifestations. Both were short with defective growth hormone secretion. Computed tomography revealed empty sella in both girls; one had widespread atrophic cortical and cerebellar changes. High doses of thiamine improved the anaemia in the first case, increased $C$ peptide secretion in both, but had no effect on the neurological abnormalities.

(Arch Dis Child 1995; 73: 251-253)
\end{abstract}

Keywords: DIDMOAD syndrome, growth hormone, empty sella, insulin.

DIDMOAD syndrome, also known as Wolfram's syndrome, is an autosomal recessive condition with diabetes insipidus, diabetes mellitus, optic atrophy, and sensorineural deafness. These four cardinal features of DIDMOAD syndrome may be accompanied by a wide variety of other abnormalities affecting the nervous system and endocrine glands. These manifestations may be explained by a gradual neuronal degenerative process. $^{1}$ A sideroblastic and megaloblastic anaemia

Royal Hospital, Muscat, Oman, Departments of Paediatrics and Endocrinology A T Soliman B Bappal A Rajab

Department of Radiology A Darwish

National Diabetes Centre

M Asfour

Correspondence to: Dr Ashraf T Soliman Paediatric Endocrinology, Royal Hospital, National Diabetes Centre, PO Box 1331 Seeb, Muscat, Code III, Oman.

Accepted 11 May 1995 has been reported and treatment with high dose thiamine has improved the anaemia in these subjects. ${ }^{2}$ An inherited abnormality of thiamine metabolism has been suggested as responsible for this multisystem degenerative disorder. $^{3}$

This study describes the early involvement of the pituitary gland in the degenerative process contributing to growth delay in two Omani girls with DIDMOAD syndrome.

\section{Case reports}

CASE 1

Patient 1 was born at term to consanguineous parents after a full term normal delivery. She initiated presented with severe pallor and failure to thrive at the age of 22 months. Her elder sister, who was deaf and diabetic, died at the age of 7 years after an attack of profound and sustained hypoglycaemia due to administration of an excessive dose of insulin by her father at home. On admission she was severely anaemic with multiple bruises, bleeding gums, haematuria, petechiae, hepatomegaly, and mild splenomegaly. She had bilateral sensorineural deafness confirmed by auditory evoked responses and bilateral partial optic atrophy. The table presents the haematological findings showing severe anaemia with moderate macrocytosis, thrombocytopenia, and leucopenia. Haemoglobin electrophoresis, and measurement of her glucose-6-phosphate dehydrogenase, and serum electrolytes, urea, and creatinine concentrations, and liver function gave normal results. The direct and indirect Coombs test and Ham's test with sucrose were negative. Serum iron, iron binding capacity, ferritin, serum B12, and folate were normal. Bone marrow cellularity was normal with megaloblastic erythropoiesis. TORCH screen and hepatitis surface antigen were negative. Insulin was started after an abnormal oral glucose tolerance test. Glycated haemoglobin $\left(\mathrm{HbA} 1_{\mathrm{C}}\right)$ was $8 \cdot 7 \%$, fasting serum $\mathrm{C}$ peptide concentrations were $<0.8 \mu \mathrm{g} / 1$ before and six minutes after intravenous glucagon $(0.1 \mathrm{mg} / \mathrm{kg})$, and insulin antibodies were not detected in the serum. She was maintained on two daily doses of insulin and oral thiamine, $50 \mathrm{mg} /$ day. All the haematological abnormalities resolved within four weeks. Her basal and glucagon stimulated serum C peptide concentrations increased significantly after six months. At the age of 4.5 years her parents discontinued thiamine for three months against medical advice. Subsequently she was admitted with severe anaemia, purpura, and hyperglycaemia. Her $\mathrm{HbAl}_{C}$ was $9 \cdot 1 \%$. She again responded to thiamine and insulin. A water deprivation test revealed urine and serum osmolality of 320 and $290 \mathrm{mmol} / \mathrm{kg}$ respectively at 0 hours and 420 and 307 $\mathrm{mmol} / \mathrm{kg}$ after eight hours. Three hours after desmopressin (DDAVP, Ferring) $20 \mu \mathrm{g}$ intranasally, urine osmolality increased to $598 \mathrm{mmol} / \mathrm{kg}$ and plasma osmolality decreased to $289 \mathrm{mmol} / \mathrm{kg}$, consistent with 
Haematological and other findings in case 1 before and after thiamine treatment

\begin{tabular}{|c|c|c|c|c|c|c|c|c|c|c|c|}
\hline & \multirow{2}{*}{$\begin{array}{l}\text { Haemoglobin } \\
(\mathrm{g} / \mathrm{l})\end{array}$} & \multirow{2}{*}{$\begin{array}{l}\text { Packed } \\
\text { cell } \\
\text { volume }\end{array}$} & \multirow{2}{*}{$\begin{array}{l}\text { Reticulocytes } \\
(\%)\end{array}$} & \multirow{2}{*}{$\begin{array}{l}\text { Total } \\
\text { leucocyte } \\
\text { count }\left(\times 10^{9} /\right)\end{array}$} & \multirow{2}{*}{$\begin{array}{l}\text { Neutrophils } \\
(\%)\end{array}$} & \multirow{2}{*}{$\begin{array}{l}\text { Platelets } \\
\left(\times 10^{9} n\right)\end{array}$} & \multirow{2}{*}{$\begin{array}{l}M C V \\
(f)\end{array}$} & \multirow{2}{*}{$\begin{array}{l}H b A 1_{C} \\
(\%)\end{array}$} & \multirow{2}{*}{$\begin{array}{l}\text { Insulin } \\
\text { (U/kg/day) }\end{array}$} & \multicolumn{2}{|c|}{$C$ peptide $(\mu g /)$} \\
\hline & & & & & & & & & & Basal & Peak after glucagon \\
\hline $\begin{array}{l}\text { Baseline } \\
\text { Day } 1 \\
\text { On thiamine }\end{array}$ & 48 & $0 \cdot 16$ & $0 \cdot 2$ & $2 \cdot 9$ & 10 & 9 & 97 & 8.9 & 1.4 & $<0.8$ & ND \\
\hline $\begin{array}{l}\text { Day } 7 \\
\text { Day } 14 \\
\text { Day } 28 \\
6 \text { Months } \\
12 \text { Months } \\
18 \text { Months } \\
\text { Off thiamine }\end{array}$ & $\begin{array}{r}68 \\
102 \\
121 \\
129 \\
132 \\
128\end{array}$ & $\begin{array}{l}0 \cdot 22 \\
0 \cdot 28 \\
0 \cdot 32 \\
0 \cdot 37 \\
0 \cdot 36 \\
0 \cdot 36\end{array}$ & $\begin{array}{r}10 \cdot 2 \\
13 \cdot 2 \\
10 \cdot 0 \\
2 \cdot 5 \\
2 \cdot 0 \\
2 \cdot 2\end{array}$ & $\begin{array}{r}6.9 \\
8.9 \\
9.9 \\
10.3 \\
11.5 \\
10.9\end{array}$ & $\begin{array}{l}19 \\
32 \\
29 \\
35 \\
44 \\
26\end{array}$ & $\begin{array}{l}128 \\
386 \\
401 \\
421 \\
410 \\
452\end{array}$ & $\begin{array}{r}94 \\
100 \\
101 \\
95 \\
97 \\
95\end{array}$ & $\begin{array}{l}\text { ND } \\
\text { ND } \\
8 \cdot 2 \\
7 \cdot 2 \\
6 \cdot 5 \\
6 \cdot 1\end{array}$ & $\begin{array}{l}1 \cdot 2 \\
1 \cdot 0 \\
0 \cdot 8 \\
0 \cdot 4 \\
0 \cdot 4 \\
0 \cdot 25\end{array}$ & $\begin{array}{r}\text { ND } \\
\text { ND } \\
<0 \cdot 8 \\
1 \cdot 2 \\
1 \cdot 1 \\
1 \cdot 3\end{array}$ & $\begin{array}{l}\text { ND } \\
\text { ND } \\
\text { ND } \\
1 \cdot 9 \\
2 \cdot 2 \\
2 \cdot 0\end{array}$ \\
\hline $\begin{array}{l}3 \text { Months } \\
\text { On thiamine }\end{array}$ & 43 & $0 \cdot 13$ & $2 \cdot 0$ & $3 \cdot 2$ & 14 & 25 & 95 & $10 \cdot 2$ & $1 \cdot 25$ & $<0.8$ & $<0.8$ \\
\hline $\begin{array}{l}1 \text { Month } \\
6 \text { Months }\end{array}$ & $\begin{array}{l}121 \\
125\end{array}$ & $\begin{array}{l}0 \cdot 29 \\
0 \cdot 35\end{array}$ & $\begin{array}{l}6 \cdot 0 \\
4 \cdot 0\end{array}$ & $\begin{array}{l}6 \cdot 3 \\
8 \cdot 9\end{array}$ & $\begin{array}{l}26 \\
34\end{array}$ & $\begin{array}{l}251 \\
395\end{array}$ & $\begin{array}{l}98 \\
98\end{array}$ & $\begin{array}{l}9 \cdot 2 \\
7 \cdot 3\end{array}$ & $\begin{array}{l}1 \cdot 2 \\
1 \cdot 2\end{array}$ & $\begin{array}{l}<0 \cdot 8 \\
<0 \cdot 8\end{array}$ & $\begin{array}{l}<0.8 \\
<0.8\end{array}$ \\
\hline
\end{tabular}

$\mathrm{MCV}=$ mean corpuscular volume; $\mathrm{ND}=$ not done.

the diagnosis of partial neurogenic diabetes insipidus. There was delayed growth (height SD score $-2 \cdot 2$ and height growth velocity 3.2 $\mathrm{cm} /$ year) with normal body mass index $(17 \cdot 3)$. Her peak growth hormone response after clonidine and insulin hypoglycaemia was 5.4 and $4.4 \mu \mathrm{g} / 1$ respectively, and serum insulin-like growth factor-I (IGF-I) concentration was $<65 \mathrm{ng} / \mathrm{ml}$ (normal range $65-450$ $\mathrm{ng} / \mathrm{ml}$ ) indicating growth hormone deficiency. Her basal ( $8 \mathrm{am})$ cortisol concentration was $351 \mathrm{nmol} / 1$ and increased to $892 \mathrm{nmol} / 140$ minutes after insulin induced hypoglycaemia. Serum free thyroxine $(14.5 \mathrm{pmol} / \mathrm{l})$ and thyroid stimulating hormone $(1.8 \mathrm{mU} / \mathrm{l})$ concentrations were normal. Her bone age was 2.5 years when the chronological age was 4.3 years. Computed tomography of the hypothalamic-pituitary area revealed a completely empty sella.

\section{CASE 2}

This girl presented at the age of 7 years with moderate developmental and growth delay, mild gait unsteadiness, tremor, and visual impairment. She was born at term to parents who were first cousins. Her paternal aunt was diabetic and deaf. Her two brothers were healthy. On examination, she had bilateral optic atrophy and nystagmus. Peak growth hormone response to clonidine $\left(0.15 \mathrm{mg} / \mathrm{m}^{2}\right)$ was $7.6 \mu \mathrm{g} / \mathrm{l}$ and IGF-I concentration $<65 \mathrm{ng} / \mathrm{ml}$. At the age of 8.8 years she presented with polyuria, polydipsia, dehydration, and nonketotic hyperglycaemia. Her height $(98.3 \mathrm{~cm})$, height growth velocity $(3.1 \mathrm{~cm} /$ year $)$, and weight $(15 \mathrm{~kg})$ were below the third centile for age and gender. Her oral glucose tolerance test was abnormal with $\mathrm{HbAl}_{\mathrm{C}}$ concentration $9.1 \%$. C peptide concentrations were $<0.8$ and $1.5 \mu \mathrm{g} / \mathrm{l}$ before and six minutes after intravenous glucagon ( $1 \mathrm{mg}$ ). Glycaemia control was achieved with two daily doses of insulin. Her renal and hepatic functions and haemogram were normal. Renal ultrasonography and an intravenous pyelogram revealed a normal urinary system. Her peak growth hormone and cortisol concentrations after insulin induced hypoglycaemia were $2.6 \mu \mathrm{g} / \mathrm{l}$ and $1116 \mathrm{pmol} / \mathrm{l}$ respectively. Her growth hormone peak after clonidine was $3 \cdot 1 \mu \mathrm{g} / \mathrm{l}$ and IGF-I $<65 \mathrm{ng} / \mathrm{ml}$. The bone age was 4.0 years. Insulin antibodies and islet cell antibodies were undetectable in the serum. After achieving adequate glycaemic control, a water deprivation test revealed serum and urine osmolalities of 298 and $242 \mathrm{mmol} / \mathrm{kg}$ respectively at 0 hours and 310 and $350 \mathrm{mmol} / \mathrm{kg}$ respectively after six hours. Three hours after DDAVP, serum and urine osmolalities were 290 and $490 \mathrm{mmol} / \mathrm{kg}$ respectively. Thiamine $100 \mathrm{mg}$ orally daily was started. After four weeks her insulin requirements halved and serum $C$ peptide concentrations before and after glucagon were 1.1 and $2.3 \mu \mathrm{g} / \mathrm{l}$. Computed tomography revealed low density pituitary fossa content consistent with empty sella, hypoplastic cerebellum with large cisterna magna and small vermis, and generalised prominence of the cortical sulci with mild dilatation of the ventricular system indicative of mild cerebral atrophy. An audiogram showed moderate bilateral high frequency hearing loss. One year after initiating insulin and thiamine treatment her $\mathrm{HbAl}_{\mathrm{C}}$ concentration was $6 \cdot 1 \%$ with no appreciable improvement in her neurological status or growth rate $(2.8 \mathrm{~cm} /$ year $)$.

\section{Discussion}

The variation in the phenotype of Wolfram's syndrome may represent the inconsistent association of closely linked inherited traits, or the pleiotropic expression of a single, recessively inherited gene. The mean ages at diagnosis of diabetes mellitus and optic atrophy are 9 and 12 years respectively. ${ }^{4}$ Hearing loss may be undetectable except by audiography before the age of 20 years. ${ }^{5}$ The ages at onset of the more variable features of Wolfram's syndrome such as the neurological, urinary tract, and endocrine abnormalities are usually recognised in the second or third decade. ${ }^{5}$ The cardinal neurological features of optic atrophy, diabetes insipidus, and hearing loss have been correlated with degeneration in the anterior visual pathway, the hypothalamic nuclei, and the vestibulocochear nuclei. The neuropathological changes described included neuronal loss, gliosis, and demyelination in the cerebellum and brainstem, and myelin pallor in spinal cord tracts. ${ }^{4}$ Most computed tomograms of patients with DIDMOAD syndrome have been normal, even in patients with ataxia, nystagmus, dysphagia, and grossly abnormal 
electroencephalography. ${ }^{6}$ In our patients we documented early involvement of the pituitary gland in the degenerative process (at the age of 4.5 and 7 years respectively), as evidenced by empty sella on computed tomography and abnormal growth hormone response to provocation.

Small stature and retarded bone age have been reported in many children with DIDMOAD syndrome but studies of the hypothalamic, pituitary, and thyroid function have been normal. ${ }^{1}$ In contrast, our cases had defective growth hormone secretion with low IGF-I concentration and normal hypothalamicpituitary-adrenal axis and normal thyroid function denoting a state of isolated growth hormone deficiency.

We confirmed the rapid and complete response of the megaloblastic-sideroblastic anaemia and significant improvement of glycaemic control in response to oral thiamine. However, improved glycaemic control lasted only two years in the first case.
No improvement of neurological status was detected after one year of high dose thiamine. The hypothesis that early treatment with thiamine might prevent progression of neurological damage remains doubtful.

1 Bertz GW, Baghadassarian A, Graber JD, Zacherle BJ, Norum RA, Blizzard RM. Coexistence of diabetes mellitus and insipidus and optic atrophy in two male siblings, studies and review of literature. Am $\mathcal{F}$ Med 1970; 48: 398-403.

2 Pignatti-Borgna C, Marradi P, Pinelli L, Monetti N, Patrini C. Thiamine-responsive anemia in DIDMOAD syndrome. 7 Pediatr 1989; 114: 405-10.

3 McGibbon BH, Mollin DL. Sideroblastic anemia in man: observations on seventy cases. Br $\mathcal{F}$ Haematol 1965; 2: 59-69.

4 Cremers CWRJ, Wijdeveld PGAB, Pinckers AJLG. Juvenile diabetes mellitus, optic atrophy, hearing loss, diabetes insipidus, atonia of the urinary tract and bladder, and other abnormalities (Wolfram syndrome). Acta Paediatr Scand abnormalities (Wolfram

5 Ikkos DG, Fraser GR, Matsouki-Gavra E. Association of juvenile diabetes mellitus, primary optic atrophy and perceptive hearing loss in three sibs, with additional idiopathic diabetes insipidus in one case. Acta Endocrinol (Copenh) 1970; 65: 95-102.

6 Fishman L, Ehrlich RM. Wolfram syndrome: report of four cases and review of literature. Diabetes Care 1986; 9: 405-8.

\title{
Management of infantile polyposis syndrome
}

\author{
G J Stiff, A Alwafi, H Jenkins, J Lari
}

\begin{abstract}
A boy with generalised infantile polyposis syndrome is reported to highlight the difficulties in management. Despite attempts to reduce polyp mass by regular endoscopic polypectomy, daily transfusions of blood products, and a trial of the non-steroidal anti-inflammatory agent sulindac, his condition gradually deteriorated and he died of septicaemia.

(Arch Dis Child 1995; 73: 253-254)
\end{abstract}

Keywords: infantile polyposis syndrome.

The term 'juvenile polyp' was coined by Horrileno and his colleagues to describe the characteristic histological appearance of polypoid hamartomas arising from the lamina propria of the colorectum within the paediatric

University Hospital of

Wales, Cardiff,

Department of

Paediatric Surgery

G J Stiff

A Alwafi

J Lari

Department of Paediatric

Gastroenterology

H Jenkins

Correspondence to: Dr G J Stiff, Department of Surgery, East Glamorgan NHS Trust, Church Village, Mid Glamorgan CF38 1AB.

Accepted 6 June 1995 age group. ${ }^{1}$ McColl and his coworkers are generally credited with the first description of multiple juvenile polyps and used the term juvenile polyposis syndrome to distinguish these patients from those with a solitary juvenile polyp. ${ }^{2}$ There are three forms of this rare condition in which polyps are limited to the colon (juvenile polyposis coli), distributed throughout the entire gastrointestinal tract (generalised juvenile polyposis), or present in infancy either as colonic or diffuse disease (infantile polyposis syndrome, IPS).

We report a case of IPS affecting the whole of the gastrointestinal tract and describe the management difficulties associated with this condition. We also report the use of the nonsteroidal anti-inflammatory agent sulindac that was used in an attempt to reduce the polyp mass.

\section{Case report}

A boy of 7 months of age presented with rectal bleeding, abdominal pain, and bile stained vomiting. There was no past history of abdominal symptoms and no family history of gastrointestinal disease. On examination there was a palpable abdominal mass in the left lower quadrant and a full blood count showed iron deficiency anaemia with a haemoglobin concentration of $86 \mathrm{~g} / \mathrm{l}$. A barium enema gave normal results but an ultrasound scan strongly suggested the diagnosis of intussusception.

A laparotomy was performed which confirmed jejunojejunal intussusception with a large $4 \mathrm{~cm}$ polyp leading the intussusceptum. In addition a large number of polyps were palpable in the rest of the small bowel as well as in the colon. Numerous polyps were removed through the enterotomy and histology showed the typical appearances of juvenile polyps. A diagnosis of the IPS was established.

Postoperatively he was noted to be oedematous and liver function tests revealed an albumin concentration of $18 \mathrm{~g} / \mathrm{l}$. He was given several infusions of salt poor albumin but his serum proteins remained low and therefore total parenteral nutrition was initiated. 